NBER WORKING PAPER SERIES

\title{
THE FLOW APPROACH TO LABOR MARKETS: NEW DATA SOURCES AND MICRO-MACRO LINKS
}

\author{
Steven J. Davis \\ R. Jason Faberman \\ John Haltiwanger \\ Working Paper 12167 \\ http://www.nber.org/papers/w12167 \\ NATIONAL BUREAU OF ECONOMIC RESEARCH \\ 1050 Massachusetts Avenue \\ Cambridge, MA 02138 \\ April 2006
}

Steven J. Davis is William H. Abbott Professor of International Business and Economics, Graduate School of Business, University of Chicago, Chicago, Illinois, Research Associate, National Bureau of Economic Research, Cambridge, Massachusetts, and Visiting Scholar, American Enterprise Institute, Washington, D.C. R. Jason Faberman is Research Economist, Office of Employment and Unemployment Statistics, Bureau of Labor Statistics, Washington, D.C. John Haltiwanger is Professor of Economics, University of Maryland, College Park, Maryland, and Research Associate, National Bureau of Economic Research, Cambridge, Massachusetts. The views expressed herein are those of the author(s) and do not necessarily reflect the views of the National Bureau of Economic Research.

(O2006 by Steven J. Davis, R. Jason Faberman and John Haltiwanger. All rights reserved. Short sections of text, not to exceed two paragraphs, may be quoted without explicit permission provided that full credit, including $\odot$ notice, is given to the source. 
The Flow Approach to Labor Markets: New Data Sources and Micro-Macro Links

Steven J. Davis, R. Jason Faberman and John Haltiwanger

NBER Working Paper No. 12167

April 2006

JEL No. J23, J64, E24

\section{ABSTRACT}

New data sources and products developed by the Bureau of Labor Statistics and the Bureau of the Census highlight the fluid character of U.S. labor markets. Private-sector job creation and destruction rates average nearly $8 \%$ of employment per quarter. Worker flows in the form of hires and separations are more than twice as large. The data also underscore the lumpy nature of micro-level employment adjustments. More than two-thirds of job destruction occurs at establishments that shrink by more than $10 \%$ within the quarter, and more than one-fifth occurs at those that shut down. Our study also uncovers highly nonlinear relationships of worker flows to employment growth and job flows at the micro level. These micro relations interact with movements over time in the crosssectional density of establishment growth rates to produce recurring cyclical patterns in aggregate labor market flows. Cyclical movements in the layoffs-separation ratio, for example, and the propensity of separated workers to become unemployed reflect distinct micro relations for quits and layoffs. A dominant role for the job-finding rate in accounting for unemployment movements in mild downturns and a bigger role for the job-loss rate in severe downturns reflect distinct micro relations for hires and layoffs.

Steven J. Davis

Graduate School of Business

The University of Chicago

5807 South Dorchester

Chicago, IL 60637

and NBER

steve.davis@gsb.uchicago.edu

R. Jason Faberman

U.S. Bureau of Labor Statistics

Postal Square Building

2 Massachusetts Ave., NE

Washington, DC 20212-0001

faberman.jason@bls.gov
John Haltiwanger

Department of Economics

University of Maryland

College Park, MD 20742

and NBER

haltiwan@bsos.umd.edu 
More than ten percent of U.S. workers separate from their employers each quarter. Some move directly to a new job with a different employer, some become unemployed, and some exit the labor force. The flow of new hires is similarly large, and somewhat larger whenever aggregate employment expands. The magnitude of hires and separations underscores the fluid character of U.S. labor markets and draws attention to questions of search and matching, recruiting, applicant screening, and employee retention. It also provides powerful motivation for theories of frictional unemployment.

The economic forces behind worker flows can be grouped into broad categories. On the "demand side," employers create new jobs and destroy old ones in large numbers every quarter. These newly created and destroyed jobs can be measured directly, and they account for much of the job mobility and many of the jobless spells experienced by workers. Workers also switch jobs and change employment status because of "supplyside" events such as labor force entry, family relocation and retirement. In addition, workers switch jobs for reasons of career development, better pay and preferable working conditions. Roughly speaking, the creation of new jobs and the destruction of old ones reflect demand-side developments in the labor market, while worker flow measures also capture supply-side events and job switching.

U.S. statistical agencies have recently developed some remarkable new datasets that yield a richer, fuller picture of labor market flows. We use these new sources and several older sources to develop evidence about the magnitude and distribution of labor market flows in the cross section and over time. We also characterize the relationship of hires, separations, quits and layoffs to the creation and destruction of jobs by individual employers. Our evidence reveals that the micro relations between worker flows and job 
flows, while complex and nonlinear, are fairly stable over the business cycle. That is, business cycle swings mainly involve shifts in the distribution of employer growth rates rather than big shifts in hires, separations and layoffs conditional on employer growth.

In line with this finding, we show that much of the time variation in hires, separations, layoffs, and unemployment flows reflect the interaction between shifts over time in the distribution of employer growth rates and relatively stable, but highly nonlinear micro relations. We also show that some unusual aspects of the labor market downturn during and after the 2001 recession are explained by the micro relations between worker flows and employment growth. Our attention to the aggregate implications of micro heterogeneity and nonlinearities follows work by Bertola and Caballero (1990), Dunne, Roberts, and Samuelson (1989), Davis and Haltiwanger (1990, 1992), Caballero and Engel (1991), Caballero (1992), Foote (1998) and others.

\section{Labor Market Flows: Concepts, Measures and Magnitudes}

\section{Basics}

For any given business and at any level of aggregation, the net change in employment between two points in time satisfies a fundamental accounting identity:

$$
\text { Net Employment Change } \equiv \underbrace{\text { Hires - Separations }}_{\text {Worker Flows }} \equiv \underbrace{\text { Creation - Destruction }}_{\text {Job Flows }}
$$

Job creation is positive for an expanding or new business, and job destruction is positive for a shrinking or exiting business. Aggregating across employers within a region or industry typically yields large positive values for both job creation and job destruction. While a single employer can either create or destroy jobs during a period, it can simultaneously have positive hires and separations. Hence, the flow of hires exceeds job 
creation, and the flow of separations exceeds job destruction. As an example, consider a business with two quits during the period and one replacement hire. The worker flows at this business consist of two separations and one hire, and there is a net change of one destroyed job. These concepts of worker flows and job flows are easily aggregated by cumulating over business establishments or firms.

To express the flows from $t-1$ to $t$ as rates, we divide by the simple average of employment in $t-1$ and $t$. This calculation yields growth rates in the interval from -200 to 200 percent with endpoints corresponding to births and deaths. This growth rate measure has become standard in work on labor market flows, because it offers important advantages relative to log changes and growth rates calculated on initial employment. In particular, it yields measures that are symmetric about zero and bounded, affording an integrated treatment of births, deaths and continuing employers. It also lends itself to consistent aggregation, and it is identical to log changes up to a second-order Taylor Series expansion. See Tornqvist, Vartia and Vartia (1985) and the appendix to Davis, Haltiwanger and Schuh (1996) for additional discussion.

Table 1 reports average job and worker flow rates for the U.S. economy at monthly, quarterly, and annual sampling frequencies based on establishment-level data from several sources. The Job Openings and Labor Turnover Survey (JOLTS) is designed to produce worker flow estimates, but manipulation of the JOLTS micro data yields estimates of job flows as well. ${ }^{1}$ According to JOLTS data, workers newly hired within the month account for more than 3 percent of employment, and the number of newly

\footnotetext{
${ }^{1}$ For more on the JOLTS data, see Clark and Hyson (2001) and Faberman (2005). The publicly available JOLTS statistics for worker flows are based on a monthly sample of approximately 16,000 establishments that commences in December 2000. Our estimates are based on a research sample of JOLTS data described in Davis, Faberman, and Haltiwanger (2006).
} 
separated workers is slightly smaller. Job creation and destruction rates in the JOLTS data are 1.5 percent per month, almost half as large as hires and separations.

Several sources are available for quarterly figures on worker flows and job flows. A quarterly JOLTS sample shows worker flow rates that exceed 9 percent of employment, and job flow rates that exceed 3 percent of employment. The JOLTS sample, however, does not capture establishment entry and exit. In contrast, the Business Employment Dynamics (BED) data are based on a virtual census of establishments, and they provide more representative estimates for quarterly job flows. ${ }^{2}$ The BED data yield much larger job flows, with average job creation and destruction near 8 percent of employment per quarter. That is, for every dozen or so filled jobs at a point in time, on average one job disappears in the following three months. In a growing economy, a somewhat larger number of new jobs are created at new and expanding establishments.

The Longitudinal Employer Household Dynamics (LEHD) data contain matched employer-employee records that allow the calculation of job and worker flows. ${ }^{3}$ The matching process is complex and lends itself to multiple estimation approaches. Here, we present one set of estimates that capture all worker flows, regardless of how long a jobworker match endures, and another set for the subset of "full-quarter" transitions. Fullquarter transitions refer to separations in the current quarter of employees who worked at the establishment during the full previous quarter, and to hires in the current quarter who continue to work at the establishment in the full following quarter. The more inclusive concept (all transitions) yields quarterly rates for hires and separations of about 25

\footnotetext{
${ }^{2}$ Published job flow statistics derived from the BED commence in 1992 and are updated quarterly. We rely on a research version of the BED created by Faberman (2006) that yields job flow statistics back to 1990 . See Pivetz et al. (2001), Spletzer et al. (2004), and Clayton and Spletzer (2005) for more on the BED data. ${ }^{3}$ See Abowd, Haltiwanger and Lane (2004) for a detailed discussion of the LEHD program. See Burgess et al. (2000) for a discussion of the relationship between worker flows and job flows in this type of data.
} 
percent of employment. Many of the transitions captured by these remarkably large worker flows reflect very short employment spells. Indeed, restricting attention to fullquarter cases yields quarterly rates of 13 percent for hires and 11 percent for separations. Quarterly job flow rates in the LEHD are half as large. Finally, Pinkston and Spletzer (2004) use the BED to produce annual job flows, which do not count establishment-level employment changes that are reversed within the year. Annual job creation and destruction are about 14 percent of employment. ${ }^{4}$

Clearly, the U.S. economy exhibits high average rates of job flows and worker flows. As we show below, this characterization holds in booms and slumps alike. Several points should be kept in mind when interpreting these flows, especially when comparing measures derived from different data sources or procedures. First, hires and separations can be measured as cumulative flows during the sampling interval or by comparing the membership of the workforce at the beginning and end of the sampling interval. Both methods respect the fundamental accounting identity, but the method of point-in-time comparisons misses employment relationships that begin and end within the sampling interval. Also, under point-in-time comparisons, shorter sampling intervals capture a larger fraction of transitory employment changes. Second, for the purposes of measuring labor market flows, "employers" can be defined at the level of establishments, firms or tax-paying entities that serve as the unit of observation. We focus on establishment-based measures of labor market flows. Third, high-quality longitudinal links are essential for accurate labor market flows. Broken links create spurious entry and exit, overstating job flows, and spurious job-to-job transitions, overstating worker flows. We focus on data

\footnotetext{
${ }^{4}$ Davis, Haltiwanger, and Schuh (1996) and Davis and Haltiwanger (1999a) present additional job flow measures and discuss the relationship between job flows at different sampling frequencies.
} 
sources with high-quality longitudinal links that are the product of many person-decades of measurement work by the statistical agencies and outside researchers.

\section{Differences by Industry}

Job flow and worker flow magnitudes vary greatly among industries. Table 2 illustrates this point by reporting BED-based quarterly job flows and JOLTS-based monthly worker flows for selected industry groups. Even for broadly defined industry groups, average job and worker flow rates vary widely. For example, job flow rates are three times larger in Construction than in Manufacturing, and worker flow rates are three times larger in Leisure \& Hospitality than in Manufacturing.

Table 2 also reports large industry differences in quit rates and layoff rates and in the quit-layoff mix of separations. Goods-producing industries, such as Construction and Manufacturing, stand out for a high ratio of layoffs to quits. At the other extreme, the layoff-quit ratio is relatively low in Retail Trade and Leisure \& Hospitality, implying that most of the separations in these industries take the form of quits. The relationship between worker flows and job flows varies across industries as well. Some industries have a nearly one-to-one relation between the number of layoffs and the number of destroyed jobs, while other industries tend to destroy more jobs than they lay off workers.

These industry differences in the magnitude and character of labor market flows have interesting implications for workforce management, the incidence of unemployment, and the response of unemployment to industry-level shocks. When normal rates of worker attrition are high, as in Leisure \& Hospitality, employers can more readily respond to negative demand shocks without resorting to layoffs. When attrition rates are low, as in Manufacturing, negative demand shocks lead to bigger layoffs. Not 
surprisingly, the incidence and duration of unemployment are much higher for layoffs than for quits. ${ }^{5}$ Thus, we hypothesize that a uniform contraction in employer growth rates results in greater unemployment among workers who separate from employers with low attrition rates. Testing this hypothesis in full is beyond the scope of this paper, but we show below that the layoff-separation ratio exhibits a strong negative relationship to employer growth rates in the cross section and over time.

The evidence in Table 2 also raises a number of deeper questions. For example, why do layoffs account for a bigger fraction of separations in goods-producing industries? Do industry differences in the prominence of layoffs reflect differences in the flexibility of wages? If so, why do differences in wage flexibility arise and persist? How effectively can employers influence recruiting and retention by altering pay levels and compensation design? Answering these questions is beyond the scope of this paper, but it is worth remarking that the LEHD is well suited to an investigation of these issues, because it contains individual earnings records and has a longitudinal matched employeremployee design.

\section{Heterogeneity and the Micro Distribution of Labor Market Flows}

Tables 1 and 2 suggest that an employer can bring about a sizable workforce reduction over a period of several months by curtailing new hires and relying on attrition. Conversely, an employer can expand over time by devoting more resources to retention while hiring at a steady pace. In fact, because most establishments undergo small percentage employment changes most of the time, many desired adjustments in workforce size can be achieved by modest changes in recruiting and retention rates. It is

\footnotetext{
${ }^{5}$ For evidence, see Leighton and Mincer (1982), Mincer (1986), Davis, Haltiwanger and Schuh (1996, Figure 6.8) and Bleakley et al. (1999, Figure 4).
} 
important to recognize this point in thinking about the nature of micro-level employment adjustments and the problem of managing workforce size for a typical employer.

For the analysis of labor market flows and their consequences, however, it is equally important to recognize that most job flows involve establishments undergoing rapid expansions or contractions. As an example, take the estimates from BED data for all nonfarm private-sector establishments in the third quarter of 2001. 31 percent of BED establishments contracted during the quarter and so contributed to job destruction. Another 26 percent expanded and so contributed to job creation. Most job destruction, 68 percent, occurred at establishments that contracted by 10 percent or more during the quarter. Perhaps more surprising, 63 percent of job creation occurred at establishments that expanded by 10 percent or more. In fact, the prevalence of such large employment changes is the norm in both booms and busts. Hence, most job destruction cannot be interpreted as the product of modest contractions achieved by normal rates of worker attrition. Neither can most job creation be seen as the outcome of modest establishmentlevel growth rates. That is, although most establishments experience little or no employment change within a quarter, job flows mainly reflect lumpy employment changes at the establishment level. ${ }^{6}$

Worker flows are less concentrated at establishments with big percentage employment changes. 53 percent of hires and 52 percent of separations take place at establishments that change employment by 5 percent or less in a given month, including 11 percent at establishments with no employment change. Another 43 percent of hires occur at establishments that expand by at least 5 percent in the month, and 42 percent of

\footnotetext{
${ }^{6}$ See section 3.4 in Davis and Haltiwanger (1999a) for additional evidence on this point. A large literature has arisen on the factors, such as nonconvex adjustment costs, leading to lumpy employment changes. See, e.g., Caballero, Engel and Haltiwanger (1997) and Cooper, Haltiwanger and Willis (2004).
} 
separations occur at establishments that contract by at least 5 percent. Layoffs are more concentrated at shrinking employers - 58 percent take place at establishments that contract by 5 percent or more during the month. Many hires (16 percent of the total) occur at contracting establishments, and many separations (22 percent) occur at expanding establishments.

\section{Labor Market Flows from the Worker Perspective}

Thus far, our discussion has centered on job and worker flows measured from the employer perspective. One can also measure worker flows from the perspective of individuals as in Blanchard and Diamond (1990), Fallick and Fleischman (2004) and Shimer (2005). These studies use longitudinal data on the employment status of individuals and cross-sectional data on the duration of ongoing employment and unemployment spells to estimate the flow of persons between jobs and the flows into and out of employment, unemployment and the labor force. Figure 1 draws on tabulations from the Current Population Survey (CPS) by Fallick and Fleischman (2004) to report average monthly flows between unemployment, employment and out of the labor force. The figure also reports the average monthly flow of job switchers, i.e., direct employerto-employer flows. For each flow, Figure 1 reports the raw number of movers (in millions), the number of movers as a percent of the population aged 16-64, and the hazard rate for movements from one labor market state or job to another.

According to Figure 1, 11.9 million persons changed labor market status from one month to the next during the 1996 to 2003 period. Another 2.8 million persons switched employers in the average month. That is, nearly 15 million workers - more than 8 percent of the working-age population - switched jobs or employment status in the average 
month. Restricting attention to employed persons: 2.6 percent switch employers from one month to the next, another 1.3 percent enter unemployment, and 2.7 percent exit the labor force. That is, 6.6 percent of employed persons switched jobs or left employment in the average month. These numbers confirm the fluid character of U.S. labor markets.

\section{Labor Market Flows: Time-Series Evidence}

\section{Job Flows}

How do labor market flows move over time? Figure 2 displays quarterly job flow rates for the private sector from 1990 to 2005, and Figure 3 shows longer series for the manufacturing sector. Figure 3 is constructed by splicing BED data for the manufacturing sector to job flows calculated by Davis and Haltiwanger (1999b) from the Longitudinal Research Database (LRD) and the older BLS Labor Turnover Survey (LTS). See Faberman (2006) for details regarding the splicing method.

The two figures confirm that job creation and destruction rates are remarkably high at all times. The manufacturing data in Figure 3 also show pronounced spikes in job destruction rates during employment downturns, as stressed by Davis and Haltiwanger (1990, 1992). The shorter BED-based series for the private sector also exhibits job destruction spikes in the 1990-91 and 2001 recessions, but they are much milder than the ones in the manufacturing sector. This pattern is consistent with Foote's (1998) evidence of manufacturing/non-manufacturing differences in the cyclical dynamics of creation and destruction.

Figures 2 and 3 also show a long downward slide in job creation rates before, during, and well after the 2001 recession. There is no such downward slide in job creation rates during or after the 1990-91 recession. Moreover, the 58-year time series 
for manufacturing shows no comparable episode with a sustained downward drift in gross job creation rates coupled with declining employment. Judging by the available evidence, such a long slide in job creation rates is not a feature of any other recession in the postwar era. However, the two figures suggest that the recent slide in job creation rates is part of a longer term fall in the overall magnitude of job flows. Davis et al. (2006) provide additional evidence for this view. They document large trend declines since the mid 1970s in the cross-sectional dispersion of employment growth rates and in the volatility of business growth rates. ${ }^{7}$

\section{Worker Flows from the Employer Perspective}

Figure 4 shows seasonally adjusted rates of hires and separations from the published Job Openings and Labor Turnover Survey (JOLTS) data. The available time series covers fewer than six years but includes the 2001 recession and aftermath. The hires rate declines from 3.8 percent of employment in December 2000 to 3.0 percent in April 2003, mirroring the downward drift in job creation observed in Figure 2. Thus, the BED and the JOLTS tell similar stories of weakness in job creation and new hires during the 2001 recession, and for more than a year thereafter. The separations rate declines modestly after the 2001 recession and then reverses course. Breaking separations into its component parts, however, shows a mild increase in layoffs during the recession and a stronger decline in quits that continues until mid 2003. A longer BLS time series on Mass Layoff Initial Claims (not reported here) more clearly shows a jump in layoff rates during the 2001 recession.

\footnotetext{
${ }^{7}$ Recent studies by Comin and Philippon (2005) and others find a trend increase in volatility among publicly traded firms. Davis et al. (2006) show that rising volatility among publicly traded firms is overwhelmed by declining volatility among privately held firms, which account for about 70 percent of private business employment.
} 
As students of the business cycle have long observed, falling (or low) quit rates and rising layoff rates are symptomatic of weak labor markets; early studies reaching this conclusion include Schlicter (1921) and Woytinsky (1942). Put differently, the mix of separations shifts from quits to layoffs during cyclical downturns. Figure 4, however, shows very mild movements in the layoff rate around the 2001 recession and modest changes in the quit-layoff mix of separations. One view holds that these patterns reflect a sharp departure from previous postwar recessions. Another view holds that the behavior of layoffs and quits around the 2001 recession simply reflects the mild character of the downturn and the delayed onset of employment growth after the recession. We provide some evidence on this issue below.

Groshen and Potter (2003) and Aaronson, Rissman and Sullivan (2004) show that layoff behavior during the 2001 recession is unusual in least one important respect. Prior to the 1990-91 recession, recessions were typically accompanied by a large surge in temporary layoffs that accounted for much of the increase in total layoffs and much of the cyclical increase in unemployment. This pattern is much weaker in the 1990-91 recession and almost completely absent in the 2001 recession. Instead, almost all of the layoffs during the 2001 recession reflect permanent separations. This feature of the 2001 recession is a significant departure from the behavior of the labor market in earlier recessions, especially those before 1990.

\section{Unemployment Inflows and Outflows}

Unemployment is one of the oldest and most studied topics in labor economics, so no discussion of labor market flows would be complete without considering unemployment inflows and outflows. Figure 5 reports monthly time series from 1976 to 
2004 for unemployment flows, as percentages of the labor force, based on estimates from the Current Population Survey (CPS). The figure shows that worker flows through the unemployment pool rise during recessions, a phenomenon that characterizes earlier postwar recessions as well (Davis, 1987). Unemployment outflows directly to employment also rise in recessions, as documented by Blanchard and Diamond (1990) and Bleakley, Ferris, and Fuhrer (1999), and they remain high during the subsequent recoveries. Figure 5 also shows that unemployment flows decline by more than a third from the early 1980s to the mid 1990s. The aging of the labor force is likely a major factor in this decline, because younger workers engage in much more job shopping (Hall, 1982 and Topel and Ward, 1992). Another factor is the previously discussed trend declines in the magnitude of job flows and the volatility of business growth rates. Unemployment inflows can be broken into four component parts: job leavers (quits), temporary layoffs, permanent layoffs, and entrants to the labor market. Spikes in temporary and permanent layoffs are prominent features of recessions in the 1970s and 1980s, but as discussed above, temporary layoffs are much less prominent in the last two recessions. Unemployment outflows include individuals who find jobs as well as those who leave the labor force. In both booms and busts, the escape rate from unemployment to employment (often termed the "job-finding rate") is high, with at least 20 percent of the unemployed finding work each month (Bleakley, Ferris, and Fuhrer, 1999; Shimer, 2005). Because unemployment escape rates are high, spikes in job destruction and layoffs lead to short-lived rises in the unemployment rate unless the spike itself is long lived. The unemployment escape rate is also highly procyclical, and movements in the 
unemployment escape rate account for most of the time variation in the unemployment rate, as recently stressed by Hall (2005) and Shimer (2005).

CPS data also show that unemployment escape rates are considerably smaller for workers on permanent layoff than for job leavers and labor force entrants. Recalling our earlier discussion, workers who are laid off are more likely to enter unemployment and, conditional on entering unemployment, they have longer unemployment spells. This effect is amplified during recessions when unemployment escape rates are generally lower. Accounting for the cyclical behavior of unemployment inflows and outflows requires a major role for movements in the job separation rate or the propensity of separated workers to become unemployed (Davis, 2005).

\section{Micro Relations and Aggregate Outcomes}

\section{Hires, Separations, and Employment Growth at the Establishment Level}

We turn now to the micro relations between worker flows and establishment growth and show that they provide considerable insight into the behavior of aggregate worker flows. Figure 6 displays the cross-sectional relationships of the hires rate and the separations rate to the establishment growth rate in the JOLTS micro data. The hires and separation rates are measured on the vertical axis as a percent of employment. The establishment growth rate is measured along the horizontal axis (also as a percent of employment). Given that most monthly employment changes are small, we focus the figure on changes between -30 and 30 percent of employment. The dotted lines emanating from the origin show the minimum number of hires (for expansions) and separations (for contractions) required to accommodate the establishment-level 
employment change. To construct Figure 6, we use pooled monthly data from December 2000 to January 2005 to estimate the mean hires rate and the mean separations rate for narrow intervals of the establishment growth rate distribution. ${ }^{8}$ The reader should interpret the curves as depicting how establishment-level hires and separations vary with the establishment growth rate. Given that job creation involves establishments with positive growth and job destruction involves establishments with negative growth, Figure 6 also shows the cross-sectional micro relations between worker flows and job flows.

Figure 6 yields several noteworthy results. First, hires and separations are highly nonlinear functions of the establishment growth rate, with sharp kinks and sign changes at zero. It will be important for the analysis below that this kink occurs in the thick part of the establishment growth rate distribution. Second, hires increase roughly one-for-one with job growth at expanding establishments, and separations increase roughly one-forone with job loss at contracting establishments. Third, separations rise more sharply to the right of zero than hires rise to the left of zero. This asymmetry reflects a greater separation propensity for new hires coupled with a greater need for new hires at expanding establishments. Finally, hires and separations rates are lowest for zero-growth establishments, implying that these establishments are stable with respect to both job growth and worker turnover.

One can decompose the separations rate in the JOLTS data into quits and layoffs. Figure 7 displays the relationships of the quit and layoff rates to the establishment growth

\footnotetext{
${ }^{8}$ Interval widths range from 0.1 percent to 5 percent, with narrower intervals closer to zero. This curvefitting method is equivalent to a least squares regression of the hires (separations) rate on a large number of dummy variables for growth rate intervals that partition the -200 to 200 percent range. In the regression approach, it is easy to include establishment fixed effects that isolate variation over time within establishments. In unreported results, we find that the patterns displayed in Figure 6 survive the inclusion of establishment fixed effects. We have also verified that the same patterns hold in data from the LEHD.
} 
rate in a similar fashion to Figure 6. Since quits and layoffs are components of total separations, their rates can lie well below the dotted lines emanating from the origin. As seen in Figure 7, quits account for a bigger portion of separations than layoffs for expanding establishments, and for establishments that contract by less than 12 percent in the month. For establishments that contract by more than 15 percent in the month, layoffs account for most of the separations. Rapidly contracting establishments show a close relationship of layoffs to job destruction.

In Davis, Faberman and Haltiwanger (2005), we explore these worker flow relations in more detail. A key finding is that the patterns depicted in Figures 6 and 7 for hires, separations and layoffs are quite similar in months with high aggregate growth and months with negative or low aggregate growth. Put differently, these functions are reasonably stable in the face of seasonal and cyclical swings in the aggregate growth rate of employment. In the next two subsections, we develop some implications for aggregate worker flows of stable nonlinear relationships of hires, separations and layoffs to establishment-level growth rates.

Accounting for Movements in Aggregate Worker Flows

Insofar as the worker flow relations in Figures 6 and 7 are stable over time, movements in aggregate hires, separations, quits and layoffs can be accounted for by movements in the cross-sectional distribution of establishment growth rates. According to this view, fluctuations in aggregate worker flows mainly reflect movements in the cross-sectional density of establishment growth rates, rather than shifts in the worker flow relations at the micro level. Furthermore, because the micro relations are highly 
nonlinear, aggregate worker flows are sensitive to the exact location and shape of the establishment growth rate distribution.

To be more precise, express the aggregate separations rate at time $t$ as the integral

$$
S_{t}=\int s_{t}(n) f_{t}(n) d n
$$

where $n$ indexes the establishment growth rate, $f_{t}(n)$ is the employment-weighted crosssectional density of establishment growth rates at $t$, and $s_{t}(n)$ is the time- $t$ micro separations relation. The integral says that the aggregate separations rate can be calculated by computing the separations relation at each $n$, weighting by the value of the density function at that point, and then integrating over all $n$. As the integral shows, movements in aggregate separations arise from shifts in the micro relation $s_{t}(n)$ and in the cross-sectional growth rate density $f_{t}(n)$.

If the micro separations relation is stable, however, then the aggregate separations rate $S_{t}$ will closely track

$$
\int \bar{s}(n) f_{t}(n) d n
$$

where $\bar{s}(n)$ is the time-averaged separations relation displayed in Figure 6. This case is illustrated in Figure 8, which shows a hypothetical shift in the density function $f_{t}(n)$ across a stable micro separations relation. The leftward shift in the density function leads to an increase in the aggregate separations rate in this illustration, because more of the mass is placed at establishments with high separation rates. Alternatively, if movements in the aggregate separations rate arise mainly from shifts in $s_{t}(n)$ over time, then the aggregate separations rate will closely track 


$$
\int s_{t}(n) \bar{f}(n) d n
$$

where $\bar{f}(n)$ is the time-averaged density function. If neither of these integral expressions closely tracks $S_{t}$, then the interaction between contemporaneous shifts in $s_{t}(n)$ and $f_{t}(n)$ is essential in accounting for movements in aggregate separations. Analogous expressions and arguments hold for hires, quits and layoffs.

How well can movements in $f_{t}(n)$ and the time-averaged micro relations depicted in Figures 6 and 7 account for movements in aggregate worker flows? Using monthly JOLTS data, we find that this type of exercise accounts for 38 percent of the movements in aggregate hires, 42 percent for separations, 11 percent for quits, and 80 percent for layoffs (Davis, Faberman and Haltiwanger, 2005). The percentage is so low for the aggregate quit rate, because the micro quits relation varies significantly over time. In particular, conditional on the establishment growth rate, quit rates tend to rise and fall with the aggregate growth rate. The story for layoffs is quite different: the micro layoff relation is highly stable within the JOLTS sample period, so that movements in $f_{t}(n)$ alone account for the lion's share of movements in aggregate layoffs. ${ }^{9}$ Explaining the Cyclical Behavior of Separations, Layoffs and Unemployment Flows

Figures 6 and 7 also suggest testable hypotheses about the cyclical behavior of aggregate hires, quits and layoffs and about how they relate to unemployment flows and the duration of unemployment spells. To see the basic idea, consider again a leftward shift in the cross-sectional density $f_{t}(n)$ of the sort that occurs when the economy swings

\footnotetext{
${ }^{9}$ We also find that movements in the $f_{t}(n)$ account for much of the seasonal and cyclical variation in aggregate hires and separations in quarterly LEHD data from 1993 to 2003. Analysis of the LEHD data also indicates that shifts over time in the micro relations are important in accounting for trend movements in aggregate hires and separations.
} 
from boom to bust. If the micro relations in Figure 7 are reasonably stable, then the leftward shift in $f_{t}(n)$ causes a rise in the ratio of layoffs to separations. (Stability of the micro relations is sufficient but not necessary.) Now recall that laid-off workers are much more likely to enter unemployment than job leavers and, conditional on becoming unemployed, they have longer spells. So, as the layoff-separations ratio rises, so too does the propensity of separated workers to become unemployed. In other words, the leftward shift in $f_{t}(n)$ that accompanies a recession brings more unemployment inflows per separated worker. In addition, the larger share of layoffs among the persons flowing into the unemployment pool is a force for lowering the escape rate out of unemployment and thus increasing the average duration of unemployment spells.

Figure 9 provides direct evidence on cyclical movements in the ratio of layoffs to separations. The figure plots the layoff-separation ratio against the employment growth rate in seasonally adjusted monthly data from two data sources: the Manufacturing Labor Turnover Survey (LTS) from 1947 to 1981, and JOLTS data for the manufacturing sector from December 2000 to January 2005. Also shown are fitted relationships from regressions of the layoff-separation ratio on a quadratic function in the growth rate of manufacturing employment. The figure shows a strong negative relationship between employment growth and the percentage of separations that take the form of layoffs. The fitted curves in Figure 9 also indicate that the layoff-separation ratio is more sensitive to employment growth at the margin when the percentage employment decline is larger. ${ }^{10}$

\footnotetext{
${ }^{10}$ The linear and quadratic terms are individually statistically significant in the LTS data and, when we pool over industries, in the JOLTS data. When we restrict the JOLTS sample to data on the manufacturing industry only (as in Figure 9), the linear and quadratic terms are jointly statistically significant, but we cannot reject the individual null hypothesis that the coefficient on the quadratic term is zero.
} 
This convex shape for the fitted curves is consistent with the micro relations in Figure 7, which show a greater layoff-quit ratio the more rapidly an establishment contracts.

What does all this mean for unemployment? Three hypotheses follow directly. First, unemployment inflows rise in a recession. The rise in unemployment inflows occurs because the leftward shift in the establishment growth rate distribution brings a greater number of separations. Second, unemployment inflows rise more than one-forone with the recessionary rise in separations. This hypothesis follows because a recession involves a change in the mix of separations. In particular, Figure 7 tells us that the ratio of layoffs to quits rises when the establishment growth rate distribution shifts to the left. The evidence in Figure 9 confirms a major element of this hypothesis. Third, the escape rate out of unemployment declines during downturns because job losers make up a larger percentage of unemployment inflows. This compositional change in the pool of unemployed persons leads to lower unemployment escape rates, and it reinforces the effects of the general tendency for job-finding rates to decline in recessions.

Other hypotheses pertain to the distinct responses of aggregate worker flows to mild and sharp downturns in aggregate employment. A mild (as in shallow) downturn slides much of the mass in the cross-sectional density along the steep portion of the micro hires relation, so that aggregate hires respond strongly. The same density shift slides along the flat portions of the micro layoffs relation, so that layoffs respond weakly. In contrast, a sharp downturn slides more of the mass along the flatter portion of the hires relation to the left of zero and the steeper portion of the layoffs relation. Hence, a sharp, severe downturn involves bigger movements in layoffs relative to hires. 
To translate these observations into a characterization of unemployment fluctuations, use the identity that links the change in the number of unemployed persons to the job-loss and job-finding rates for workers. In the simple case with a constant labor force, the discrete-time version of this identity is

$$
\Delta U_{t}=l_{t-1} E_{t-1}-f_{t-1} U_{t-1}
$$

where $l$ is the job-loss rate for employed persons $E, f$ is the job-finding rate for unemployed persons $U$, and $t$ indexes the time period. Because the hires rate drives the job-finding rate, and the layoff rate drives the job-loss rate, the micro relations for hires and layoffs in Figures 6 and 7 yield the following two-part hypothesis. First, changes over time in the job-finding rate dominate unemployment rate movements, more so in connection with mild contractions in aggregate employment. Second, changes over time in the job-loss rate account for a bigger fraction of unemployment rate movements in connection with sharp contractions in aggregate employment. This hypothesis appears to fit the evidence on postwar U.S. unemployment fluctuations in Shimer (2005).

\section{The 2001 Recession and Subsequent Downturn}

The 2001 recession was relatively mild and brief, officially starting in March and ending in November according to the National Bureau of Economic Research. At no time did aggregate employment fall abruptly the way it had in several other postwar recessions. Yet while the initial shock to the labor market was small from a historical perspective, its effects lasted well past the end of the recession, with employment losses continuing until mid-2003. Nonfarm employment did not return to its pre-recession peak until early 2005. 
We have already discussed many of the labor market characteristics related to this downturn. Let us now take stock of the downturn and summarize some of its key aspects from a labor flows perspective. First, as with other recessions, the job destruction rate jumped in 2001, but the surge was modest, especially compared to the historical pattern in manufacturing (Figures 2 and 3). Second, a persistent downward drift in the job creation rate began in late 1999, well before the recession's onset in March 2001, and continued for 7 quarters after the recession's end (Figure 2). Hires also drifted downward during and well after the recession (Figures 4). Third, the layoff rate rose modestly during the 2001 recession, while the quit rate drifted downward during and after the recession (Figure 4). Fourth, the flow of workers through the unemployment pool during the 2001 recession rose modestly compared to previous recessions (as illustrated in Figure 5). Fifth, there was no upsurge in temporary layoff unemployment, a sharp departure from previous recessions. And finally, research by Faberman (2006) suggests that the latest downturn is unique in its persistently low rates of job creation, and that these low rates are part of a longer term decline in the magnitude of job flows.

Our analysis indicates that some of these features reflect two factors: the mild character of the recent downturn, and the secular decline in the employment share of cyclically sensitive goods-producing industries. Mild employment contractions give rise to little or no increase in the aggregate separation rate, because the cross-sectional distribution of establishment growth rates remains centered near zero, which is the trough in the micro separations relation (Figure 6). For a similar reason, the layoff rate and layoff share of separations also rise modestly in a mild contraction, as implied by Figure 
7 and confirmed in Figure 9. In turn, a modest rise in layoffs produces a modest rise in unemployment inflows and outflows.

Historically, goods-producing industries, especially construction and durable-goods manufacturing, are more cyclically sensitive than service-producing industries. In particular, service-producing industries are less prone to the violent contractions that give rise to spikes in job destruction, layoffs and unemployment inflows. Thus, one explanation for the mild character of the 2001 and 1990-91 recessions rests on the shrinking share of employment in cyclically sensitive industries. Because this trend is likely to continue, we anticipate that future recessions will also tend to have a relatively mild character and to involve modest surges in job destruction, layoffs and unemployment inflows. Nonetheless, if one or more large negative shocks causes aggregate employment to contract sharply, our analysis implies that layoffs and unemployment inflows will spike sharply, as they did in the deep recessions of the 1970s and 1980s. In this regard, we emphasize that the nonlinear worker flow relations in Figures 6 and 7 imply that layoffs and unemployment inflows are more sensitive to aggregate employment contractions on the margin when the contraction is deeper and more abrupt.

The virtual absence of a surge in temporary layoff unemployment in the 2001 recession is a striking departure from past recessions. The 1990-91 recession also involves a relatively small surge of temporarily laid off workers into the unemployment pool. In part, these developments reflect the declining share of employment in construction and manufacturing, two industry groups that have traditionally relied most heavily on temporary layoffs during downturns, but there is clearly more to the story. It is 
unclear to us why temporary layoffs were so unresponsive in the 2001 recession. Lacking a fuller explanation for their behavior in the most recent recession, it is difficult to assess whether temporary layoffs will figure prominently in future recessions.

The long downward slide in the job creation rate is another striking feature of the recent downturn. As we remarked, this slide began more than a year before the 2001 recession and continued for more than a year afterwards. This fact suggests the downward slide in job creation is part of a longer term development in the U.S. economy, an inference reinforced by Figures 2 and 3. The factors behind this secular decline in the magnitude of job flows probably contributed, albeit modestly, to the nearly four-year slide in private sector job creation rates that commenced in late 1999.

Aggregate employment did not resume a pattern of sustained growth until the latter part of 2003. A full explanation for this sluggish employment performance in the aftermath of the 2001 recession is beyond the scope of our analysis, but a likely contributing factor is the strength and duration of the expansion in the 1990s. The ratio of employed persons to the working-age population rose from 61.2 percent at the end of 1991 to 64.7 percent in mid-2000 and then fell back to 62.1 percent in late 2003 . The employment-population ratio in 2000 is an historical peak that reflects a rise of about 9 percentage points since the early 1960s. The large secular increases in the employmentpopulation ratio and the labor force participation rate may have fully played out by the late 1990s. 


\section{Concluding Remarks}

New data sources like the Business Employment Dynamics (BED), the Job Openings and Labor Turnover Survey (JOLTS) and the Longitudinal EmployerHousehold Dynamics (LEHD) program provide a strong empirical foundation for the flow approach to labor market analysis. These data sources confirm the remarkable magnitude of labor market flows. Quarterly job creation and destruction rates average nearly 8 percent of employment in the U.S. private sector. Among workers with job tenure of at least three months, nearly 11 percent separate from their employers in an average quarter. And more than 8 percent of the working-age population changes employer or labor market status from one month to the next. The data also confirm the lumpy nature of micro-level employment adjustments. Nearly two-thirds of all job creation and destruction occurs at establishments that shrink or grow by more than 10 percent within the quarter.

Another key theme to emerge from our study is the link between micro-level behavior and aggregate outcomes. Our study uncovers highly nonlinear relationships between worker flows and job flows at the micro level. We show how these micro relations interact with shifts over time in the cross-sectional distribution of establishment growth rates to produce recurring cyclical patterns in aggregate labor market flows. Cyclical movements in layoffs' share of separations, for example, as well as the propensity of separated workers to become unemployed reflect distinct micro relations for quits and layoffs. The distinct micro relations for hires and layoffs imply that the relative contribution of job-loss and job-finding rates to unemployment movements depends on whether an employment downturn is shallow or deep. 
Other evidence documented in our study also merits attention. First, the magnitude of job flows has trended downward in recent decades. This trend dates back to the 1960s in the manufacturing sector, and it appears to hold for the private sector as a whole in the period since 1990 covered by the BED. On a related note, the private-sector (gross) job creation rate began declining well before the 2001 recession and continued to slide until the middle of 2003. Based on the available evidence, the recent downturn stands out for an unusually long, steady slide in the job creation rate. Second, industries differ greatly in worker turnover rates and in employer reliance on layoffs as a tool for adjusting employment levels. These industry differences raise interesting questions about the role of pay levels, wage flexibility and compensation design in the magnitude and character of worker flows. New data sources on labor market flows developed by the Bureau of Labor Statistics and the Bureau of the Census make it possible to explore these and many other issues.

\section{Acknowledgements}

We thank Rick Clayton, John Wohlford, Jim Spletzer, Timothy Taylor, Michael Waldman, James Hines and seminar participants at Tokyo University and the University of Chicago for helpful comments and Marios Michaelides and Sasan Bahktiari for superb research assistance. Davis gratefully acknowledges financial support from the University of Chicago Graduate School of Business. The views expressed are solely those of the authors and do not necessarily reflect the official positions or policies of the U.S. Bureau of Labor Statistics, the U.S. Bureau of the Census or the views of other staff members. 


\section{References}

Aaronson, Daniel, Ellen R. Rissman, and Daniel G. Sullivan (2004) "Can Sectoral Reallocation Explain the Jobless Recover?" Federal Reserve Bank of Chicago Economic Perspectives, Second Quarter, 36-49.

Abowd, John M. Haltiwanger, John C., and Lane, Julia I., 2004. "Integrated Longitudinal Employee-Employer Data for the United States." American Economic Review Papers and Proceedings, 94(2): 224-229.

Blanchard, Oliver J., and Diamond, Peter, 1990. "The cyclical behavior of the gross flows of U.S. workers." Brookings Papers on Economic Activity, Vol. 2: 85-143.

Bleakley, Hoyt, Anne. E. Ferris, and Jeffrey C. Fuhrer, 1999. "New Data on Worker Flows During Business Cycles," New England Economic Review, July/August, pp. 49-76.

Burgess, Simon, Lane, Julia I., and Stevens, David, 2000. "Job flows, worker flows, and churning." Journal of Labor Economics 18(3): 473-502.

Caballero, Ricardo. 1992, "A Fallacy of Composition," American Economic Review 82(5), December, 1279-1292.

Caballero, Ricardo and Giuseppe Bertola, 1990, "Kinked Adjustment Costs and Aggregate Dynamics," NBER Macroeconomics Annual 1990, Cambridge: The MIT Press.

Caballero, Ricardo and Eduardo Engel. 1991, "Dynamic $(S, s)$ Economies," Econometrica 59(6), November, 1659-1686

Caballero, Ricardo, Eduardo Engel and John Haltiwanger. 1997, "Aggregate Employment Dynamics: Building From Microeconomic Evidence," $\underline{\text { American }}$ Economic Review, March 1997, 115-137.

Clark, Kelly A., and Hyson, Rosemary, 2001. "New tools for labor market analysis: JOLTS.” Monthly Labor Review 124(12): 32-37.

Clayton, Rick and James Spletzer, 2005. “Business Employment Dynamics.” Mimeo.

Comin, Diego and Thomas Philippon, 2005, "The Rise in Firm-Level Volatility: Causes and Consequences," paper prepared for the NBER Macro Annual Conference, March 25.

Cooper, Russell, John Haltiwanger and Jonathan Willis, 2004, "Dynamics of Labor Demand: Evidence from Plant-Level Observations and Aggregate Implications," NBER Working Paper No. 10297, February. 
Davis, Steven J., 1987, "Fluctuations in the Pace of Labor Reallocation," CarnegieRochester Conference Series on Public Policy, 27, 335-402.

Davis, Steven J., 2005, Comment on "Job Loss, Job Finding, and Unemployment in the U.S. Economy over the Past Fifty Years" by Robert E. Hall. Forthcoming in the NBER Macroeconomics Annual.

Davis, Steven J., Faberman, R. Jason, and Haltiwanger, John C., 2005. “The Flow Approach to Labor Markets: New Data Sources, Micro-Macro Links and the Recent Downturn," IZA Working Paper No. 1639.

Davis, Steven J., Faberman, R. Jason, and Haltiwanger, John C., 2006. "Worker Flows, Job Flows and Vacancy Postings: Market and Micro-Level Relationships." mimeo.

Davis, Steven and Haltiwanger, John C., 1990. "Gross job creation and destruction: Microeconomic evidence and macroeconomic implications." In NBER Macroeconomics Annual 5 (pp. 123-68). Cambridge, MA: National Bureau for Economic Research.

Davis, Steven and Haltiwanger, John C., 1992. "Gross job creation, gross job destruction and employment reallocation.” Quarterly Journal of Economics 107(3): 819-63.

Davis, Steven and Haltiwanger, John C., 1998. "Measuring gross worker and job flows." In John C. Haltiwanger, Marilyn Manser and Robert Topel (eds.) Labor Statistics Measurement Issues, Chicago, IL: University of Chicago Press.

Davis, Steven and Haltiwanger, John C., 1999a. "Gross job flows.” In Orley Ashenfelter and David Card (eds.), Handbook of Labor Economics, Volume 3 (pp. 27112805). Amsterdam: Elsevier Science.

Davis, Steven J. and John Haltiwanger, 1999b. "On the Driving Forces Behind Cyclical Movements in Employment and Job Reallocation," American Economic Review, 89 , no. 5, 1234-1258.

Davis, Steven, Haltiwanger, John C., Jarmin, Ron, and Miranda, Javier, 2006. "Volatility and Dispersion in Business Growth Rates: Publicly Traded versus Privately Held Firms." Paper prepared for the 2006 NBER Macroeconomics Annual.

Dunne, Timothy, Roberts, Mark J., and Samuelson, Larry, 1989b. "The growth and failure of U.S. manufacturing plants." Quarterly Journal of Economics 104(4): 671-98.

Faberman, R. Jason. 2005. "Studying the Labor Market with the Job Openings and Labor Turnover Survey." BLS Working Paper No. 388 (December). 
Faberman, R. Jason. 2006. "Job Flows and the Recent Business Cycle: Not all "Recoveries" are Created Equal.” BLS Working Paper No. 391 (February).

Fallick, Bruce and Charles A. Fleischman, 2004, "Employer-to-Employer Flows in the U.S. Labor Market: The Complete Picture of Gross Worker Flows," mimeo.

Foote, Christopher, 1998. "Trend employment growth and the bunching of job creation and destruction." Quarterly Journal of Economics 113(3): 809-834.

Groshen, Erica L. and Simon Potter (2003) "Has Structural Change Contributed to a Jobless Recover," Federal Reserve Bank of New York Current Issues in Economics and Finance, 9, no. 8 (August)

Hall, Robert E. (1982) "The Importance of Lifetime Jobs in the U.S. Economy," American Economic Review, 72, no. 4 (September), 716-724.

Hall, Robert E. (2005) "Job Loss, Job Finding, and Unemployment in the U.S. Economy over the Past Fifty Years." Forthcoming in the NBER Macroeconomics Annual.

Leighton, Linda and Jacob Mincer (1982) "Labor Turnover and Youth Unemployment," in The Youth Labor Market Problem: Its Nature, Causes and Consequences, edited by Richard Freeman and David Wise. Chicago: University of Chicago Press.

Mincer, Jacob (1986) "Wage Changes in Job Changes," Research in Labor Economics, $8 A, 171-197$

Pinkston, Joshua C. and James R. Spletzer. 2004, "Annual measures of gross job gains and gross job losses." Monthly Labor Review, Vol. 127, No. 11, 2004, pp. 3-13.

Pivetz, Timothy R.; Searson, Michael A. and Spletzer, James R. "Measuring Job Flows and the Life Cycle of Establishments with BLS Longitudinal Establishment Microdata," Monthly Labor Review, April 2001, 124(4), pp. 13-20.

Shimer, Robert, 2005 "Reassessing the Ins and Outs of Unemployment", mimeo, University of Chicago.

Slichter, Sumner H., 1921. The Turnover of Factory Labor. New York: D. Appleton and Company.

Spletzer, James R., R. Jason Faberman, Akbar Sadeghi, David M. Talan, and Richard L.Clayton. 2004, "Business Employment Dynamics.” Monthly Labor Review, Vol. 127, No. 4, April, pp. 3-8. 
Topel, Robert H. and Michael P. Ward (1992) "Job Mobility and Careers of Young Men," Quarterly Journal of Economics, 107, no. 2. (May), 439-480.

Tornqvist, Leo, Pentti Vartia, and Yrjo Vartia, 1985. "How Should Relative Change Be Measured?" American Statistician, 39, no. 1 (February), 43-46.

Woytinsky, W.S. (1942) Three Aspects of Labor Dynamics: A Report Prepared for the Committee on Social Security. Washington, D.C.: Social Science Research Council. Reprinted in 1974 by Greenwood Press in Westport, Connecticut. 
Figure 1. Average Monthly Worker Flows, Current Population Survey, 1996-2003

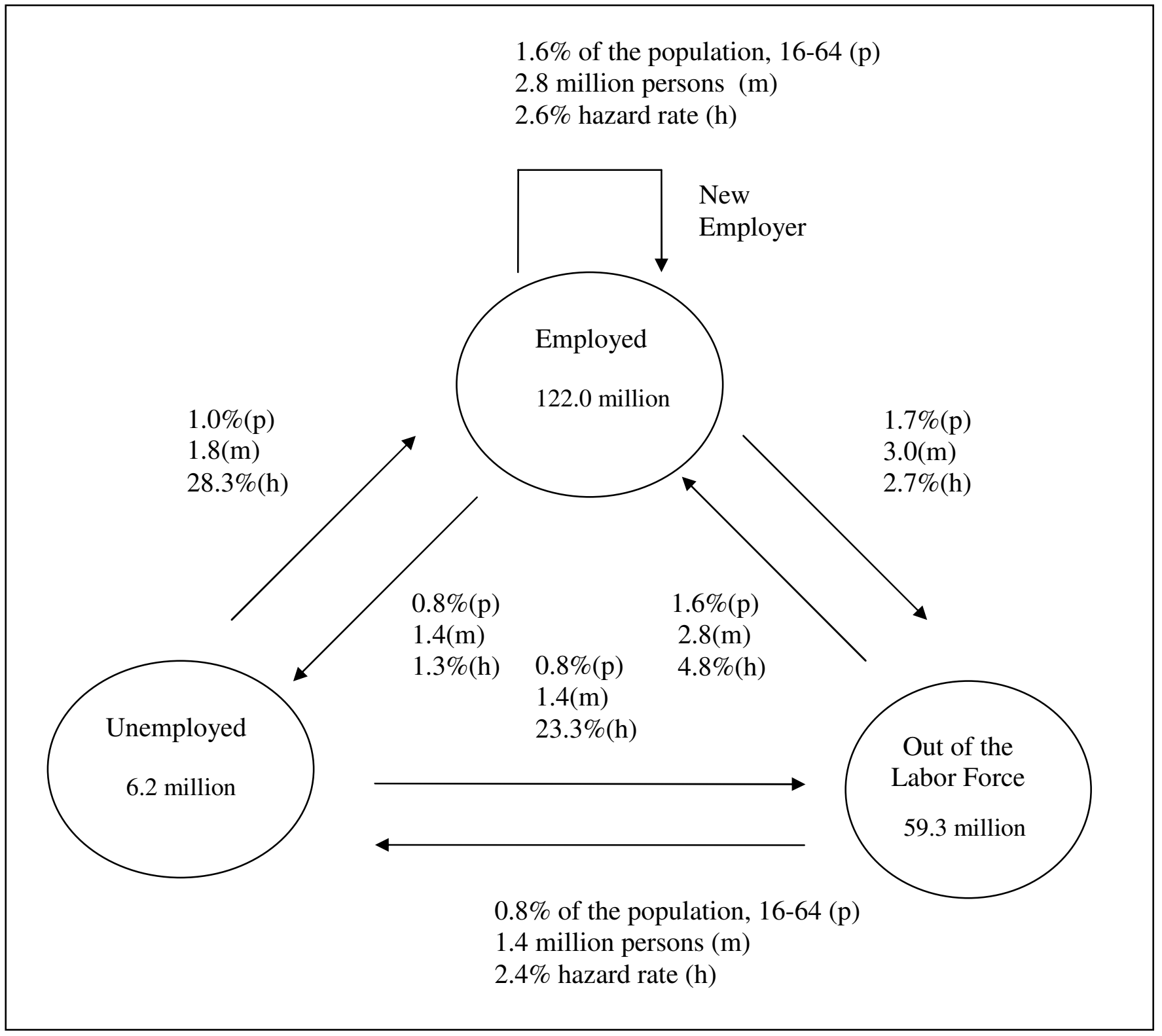

Source: Fallick and Fleischman (2004). 
Figure 2. Quarterly Job Flows in the Private Sector, 1990-2005

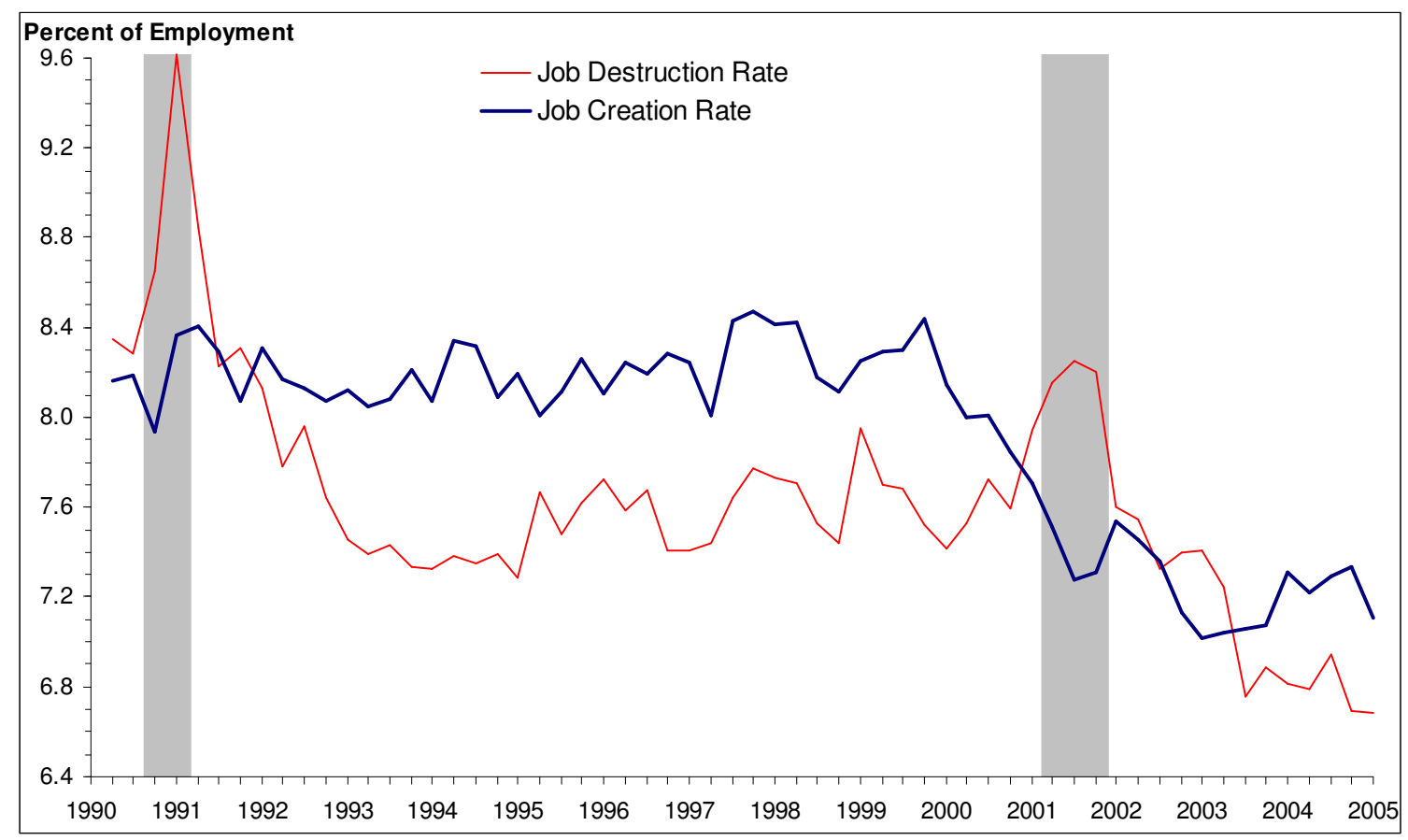

Source: Faberman (2006); tabulated from BLS Business Employment Dynamics (BED) micro data. Shaded areas show NBER-dated recessions. 
Figure 3. Quarterly Job Flows in Manufacturing, 1947-2005

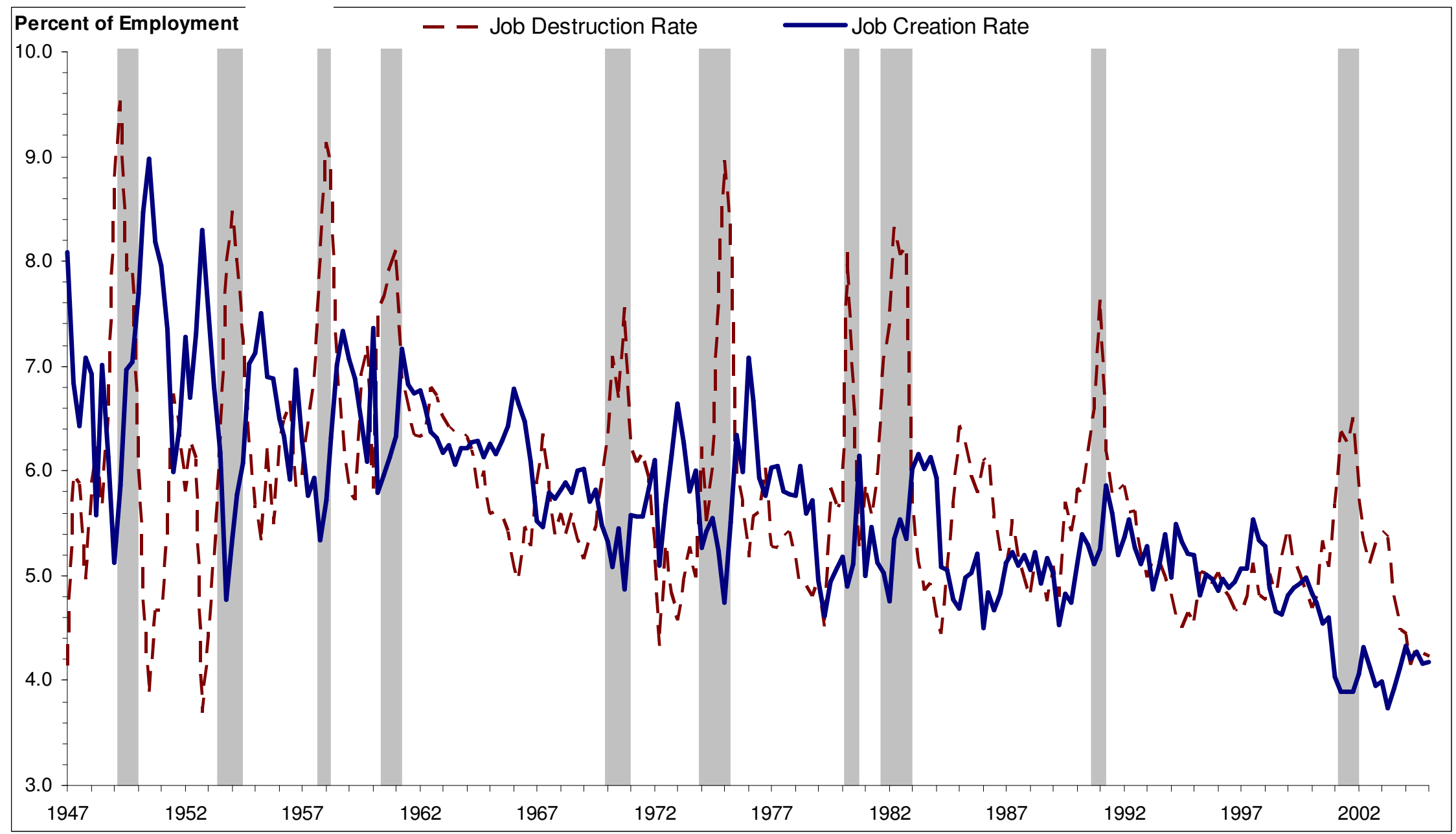

Source: Faberman (2006); tabulated from the BLS Business Employment Dynamics (BED) micro data from 1990 to 2005 and spliced to estimates for earlier periods by Davis and Haltiwanger (1999b) using data from the BLS Labor Turnover Survey (LTS) and the Census Longitudinal Research Datafile (LRD). Shaded areas show NBER-dated recessions. 
Figure 4. Monthly Worker Flow Rates, December 2000 to March 2005

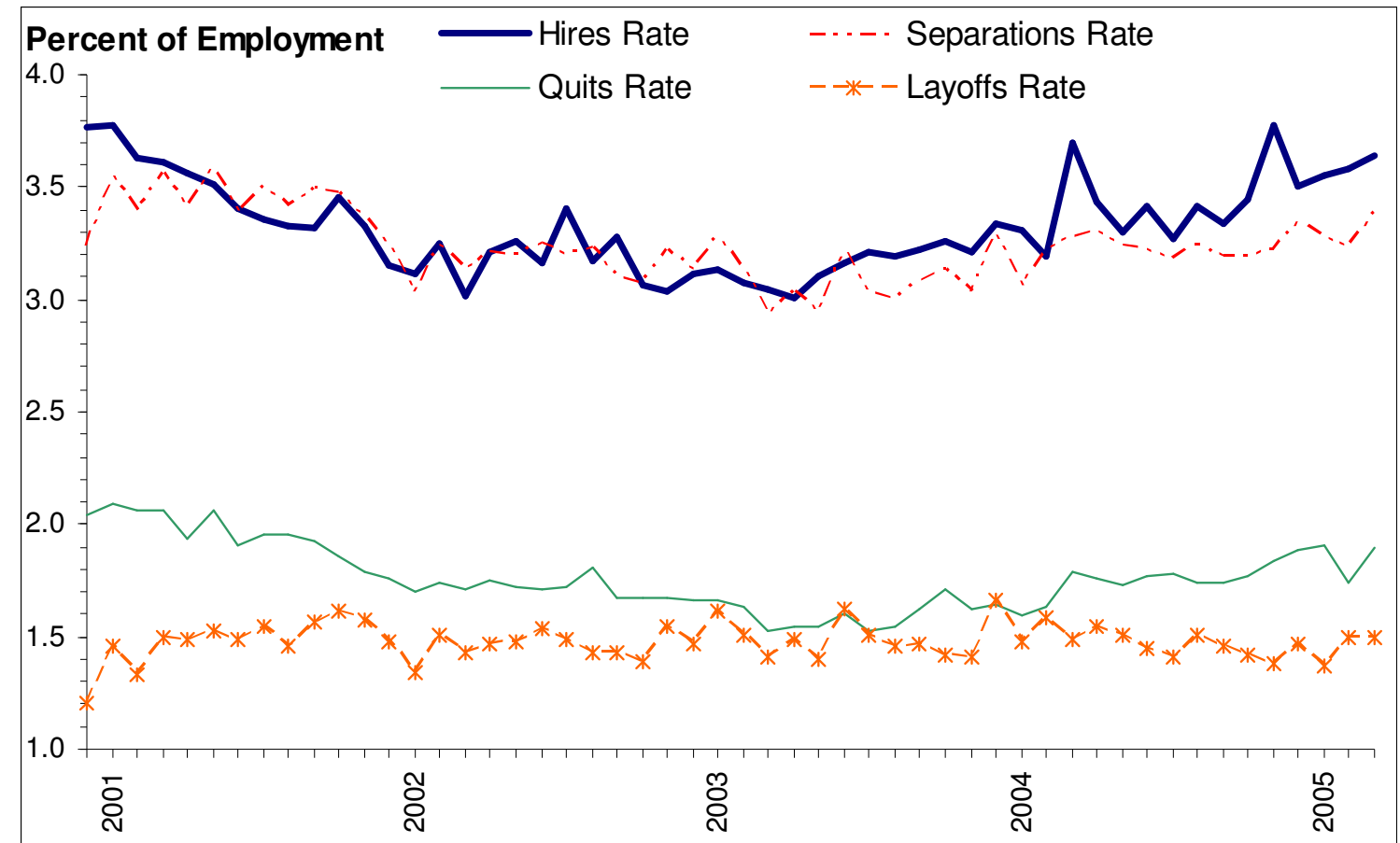

Source: Published data from the BLS Job Openings and Labor Turnover Survey (JOLTS). 
Figure 5. Monthly Unemployment Inflows and Outflows, 1976-2005

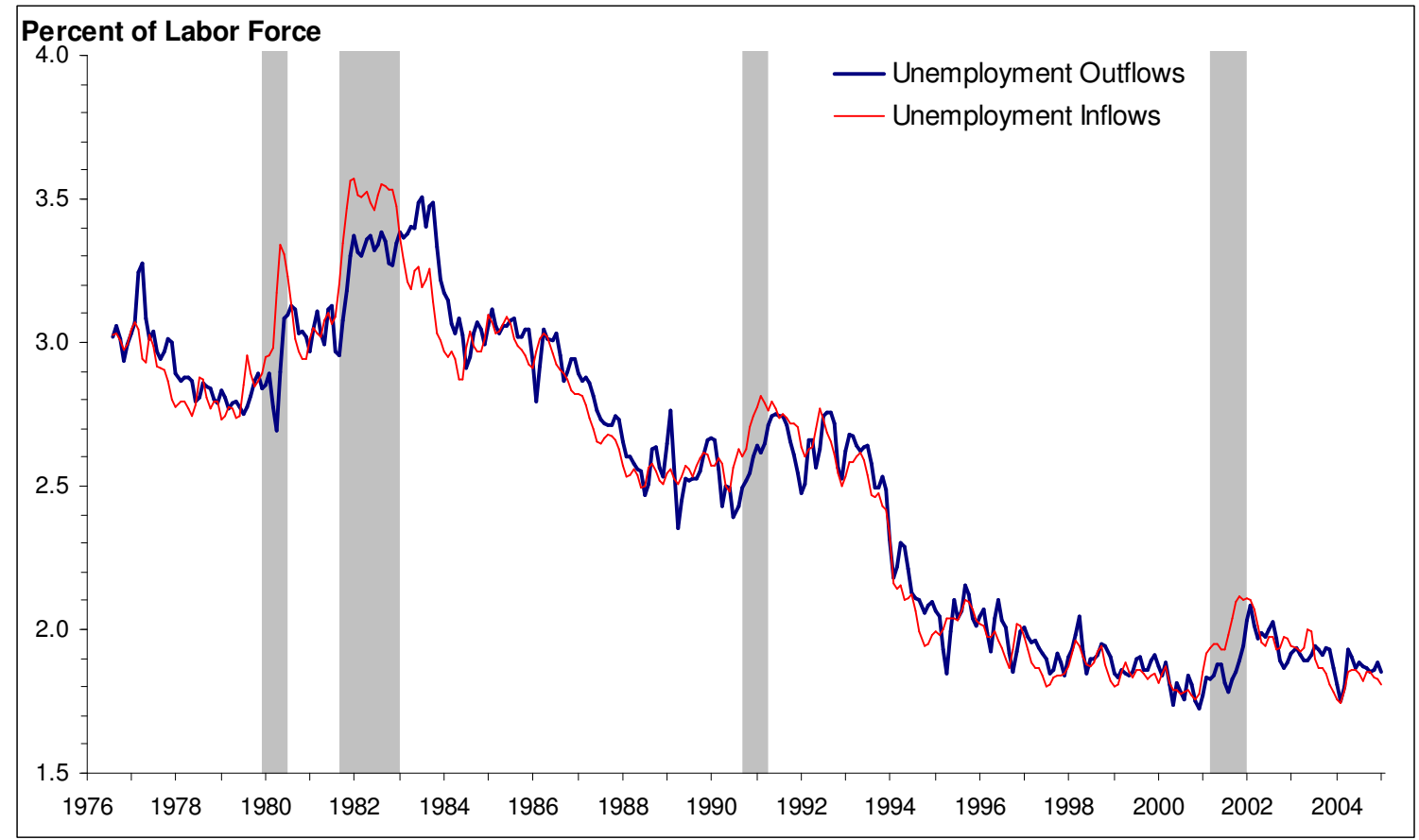

Notes: The figure depicts three-month centered moving averages of estimated gross flows of persons into and out of unemployment based on Current Population Survey (CPS) data. Shaded areas show NBER-dated recessions. 
Figure 6: The Relationship of Hires and Separations to Establishment Growth

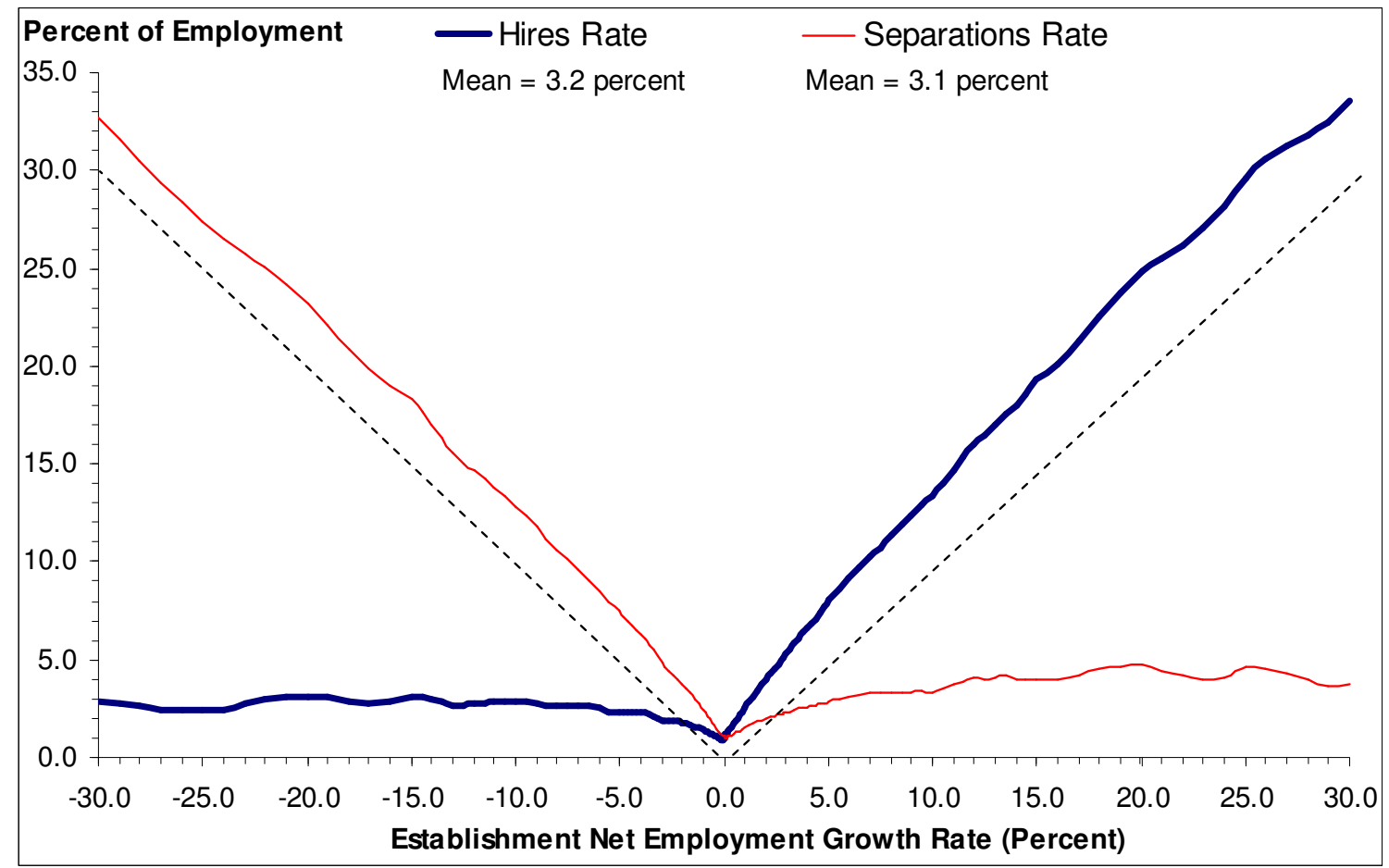

Notes: The curves are fitted values from nonparametric regressions of establishment-level hires and separations rates (vertical axis) on establishment-level employment growth rates (horizontal axis). The curves are fitted to monthly establishment-level JOLTS data pooled over the period from December 2000 to January 2005. 
Figure 7. The Relationship of Quits and Layoffs to Establishment Growth

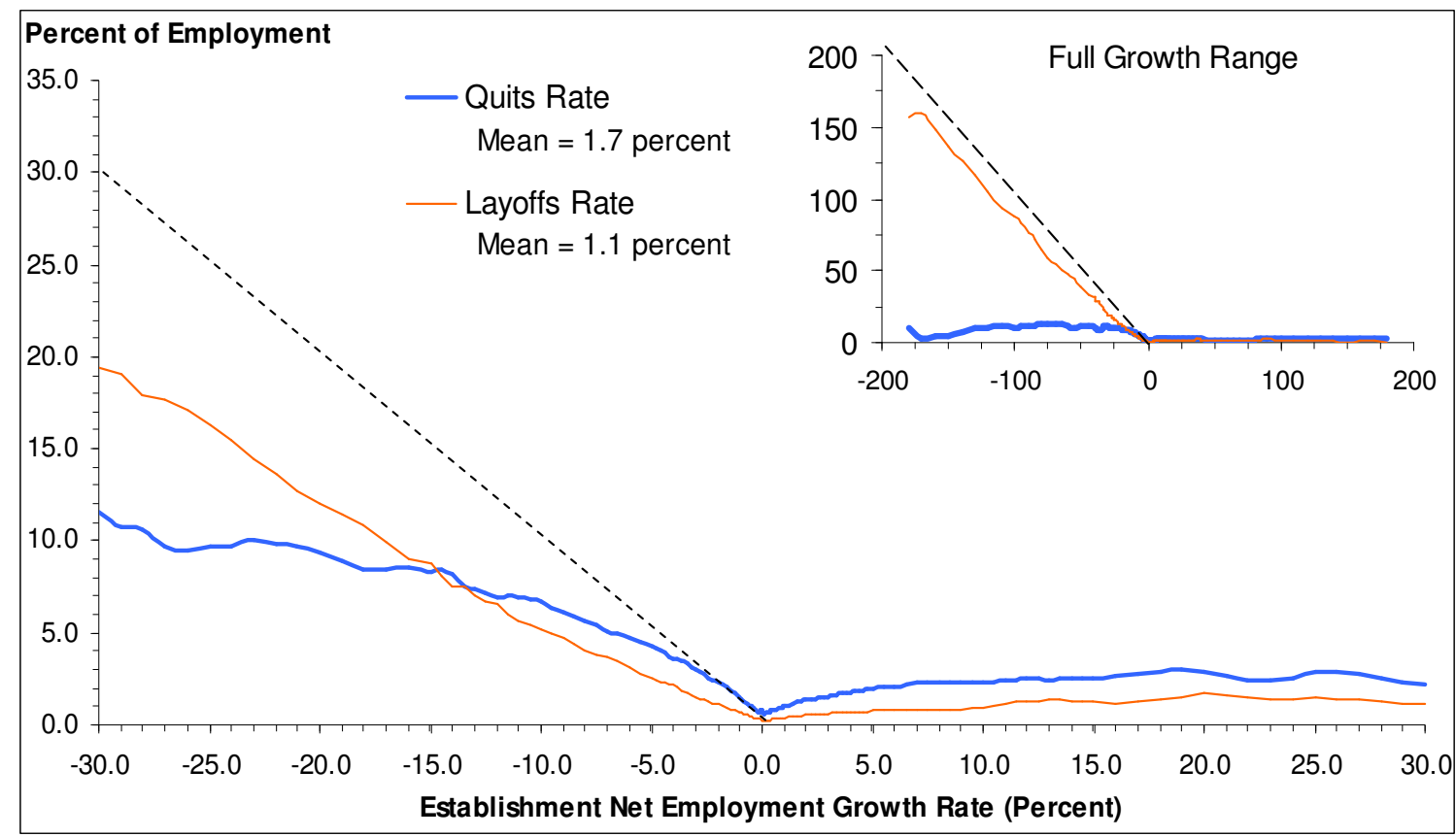

Notes: The curves are fitted values from nonparametric regressions of establishment-level layoff and quit rates (vertical axis) on establishment-level employment growth rates (horizontal axis). The curves are fitted to monthly establishment-level JOLTS data pooled over the period from December 2000 to January 2005 
Figure 8. Hypothetical Shift in the Cross-Sectional Density of Employer Growth Rates with a Stable Micro Separations Relation

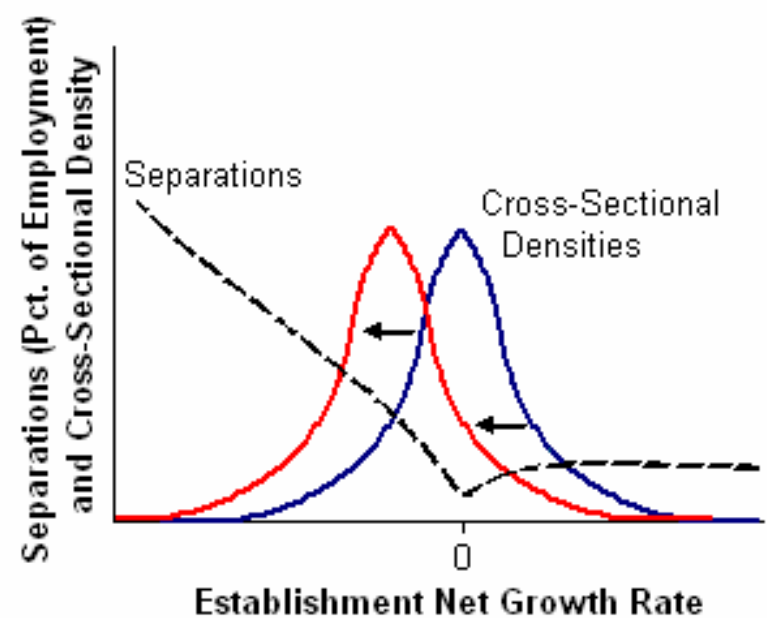

Note: The figure illustrates a hypothetical leftward shift in the cross-sectional density of employer growth rates when the economy swings from expansion to recession. The figure also shows a stable micro relationship between worker separations and employer growth rates based on the fitted separations relation in Figure 6. 
Figure 9. Layoffs-Separation Ratio as a Function of the Net Employment Growth Rate, Manufacturing Sector, Seasonally Adjusted Monthly Data

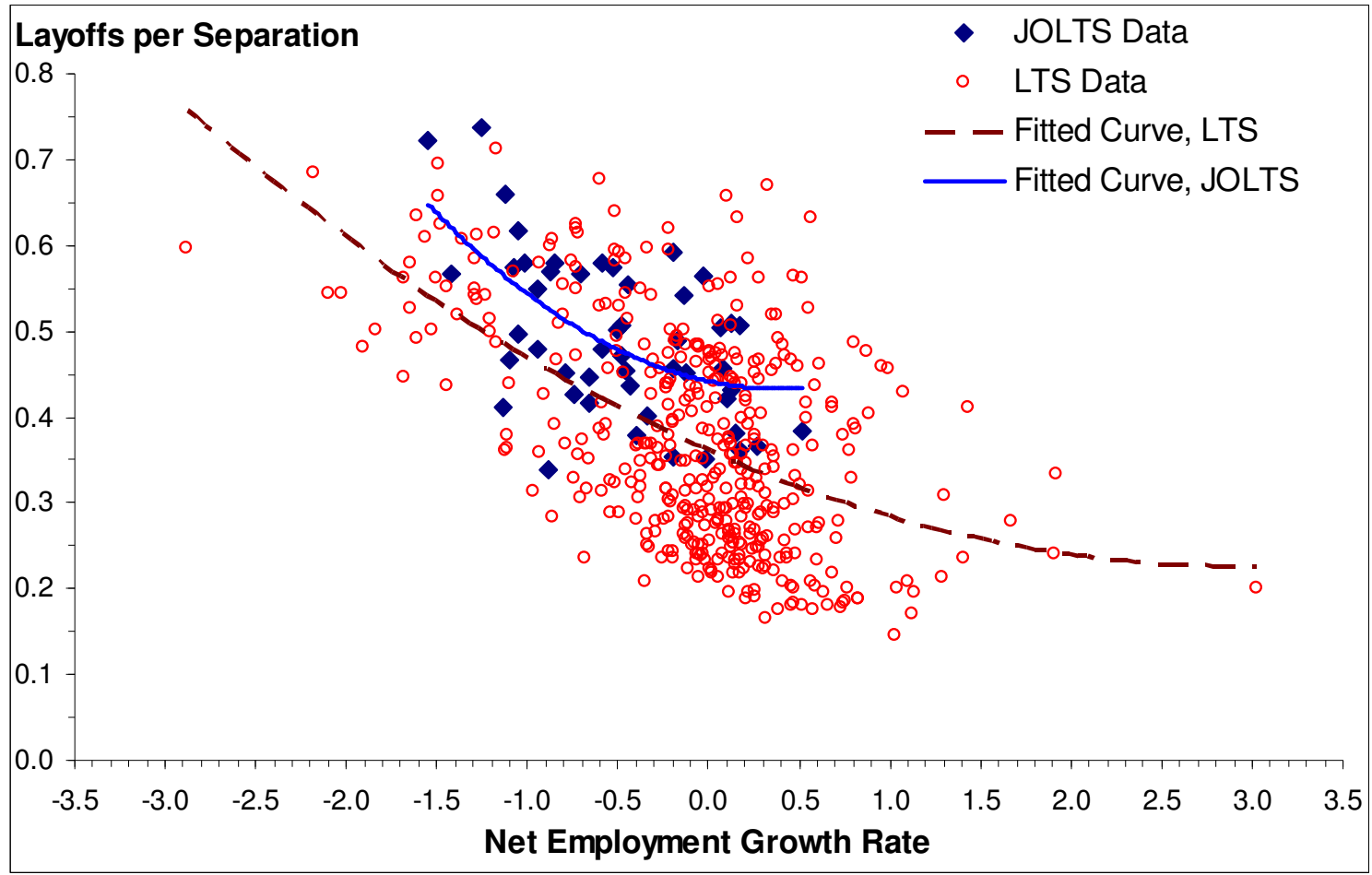

Note: The plotted curves are fitted values from two separate regressions of the layoffseparation ratio on a quadratic polynomial on the net employment growth rate. The data are monthly. 
Table 1. Job and Worker Flow Rates by Sampling Frequency and Data Source

\begin{tabular}{|c|c|c|c|c|}
\hline $\begin{array}{l}\text { Sampling Frequency } \\
\text { and Data Source }\end{array}$ & $\begin{array}{c}\text { Job } \\
\text { Creation } \\
\end{array}$ & $\begin{array}{c}\text { Job } \\
\text { Destruction } \\
\end{array}$ & Hires & Separations \\
\hline \multicolumn{5}{|l|}{ Monthly } \\
\hline $\begin{array}{l}\text { JOLTS, continuous monthly units } \\
\text { from microdata, Dec-00 to } \\
\text { Jan-05 }\end{array}$ & 1.5 & 1.5 & 3.2 & 3.1 \\
\hline \multicolumn{5}{|l|}{ Quarterly } \\
\hline $\begin{array}{l}\text { JOLTS, continuous quarterly } \\
\text { units from microdata, Dec-00 to } \\
\text { Jan-05 }\end{array}$ & 3.4 & 3.1 & 9.5 & 9.2 \\
\hline $\begin{array}{l}\text { BED, all private establishments, } \\
\text { 1990:2-2005:1 }\end{array}$ & 7.9 & 7.6 & --- & --- \\
\hline $\begin{array}{l}\text { LEHD, all transitions, ten } \\
\text { selected states, 1993:2-2003:3 }\end{array}$ & 7.0 & 6.0 & 25.0 & 24.0 \\
\hline $\begin{array}{l}\text { LEHD, “full-quarter" transitions, } \\
\text { ten selected states, 1993:2- } \\
\text { 2003:3 }\end{array}$ & 7.6 & 5.2 & 13.1 & 10.7 \\
\hline \multicolumn{5}{|l|}{ Annual } \\
\hline $\begin{array}{l}\text { BED, from Pinkston and Spletzer } \\
\text { (2004), private establishments, } \\
\text { 1998-2002 }\end{array}$ & 14.6 & 13.7 & --- & --- \\
\hline
\end{tabular}

Notes: Unless otherwise noted, estimates are from authors' tabulations using the listed data sources. The "full-quarter cases" in the LEHD restrict attention to separated workers who were employed in the quarter prior to separation and to hires who remained employed in the following quarter. Rates are percentages of employment, calculated as described in the text. 
Table 2. Job and Worker Flows by Selected Industries

A. Average Quarterly Job Flow Rates in the BED, 1990:2 - 2005:1

\begin{tabular}{|l|ccc|}
\hline & Job Creation & Job Destruction & Net Growth \\
\hline Total Private & 7.9 & 7.6 & 0.3 \\
\hline Construction & 14.3 & 13.9 & 0.4 \\
Manufacturing & 4.9 & 5.3 & -0.4 \\
Retail Trade & 8.1 & 7.9 & 0.2 \\
Professional \& & 9.9 & 9.1 & 0.8 \\
Business Services & 10.7 & 10.2 & 0.5 \\
Leisure \& Hospitality & & & \\
\hline
\end{tabular}

B. Average Monthly Worker Flow Rates in JOLTS, December 2000 to January 2005

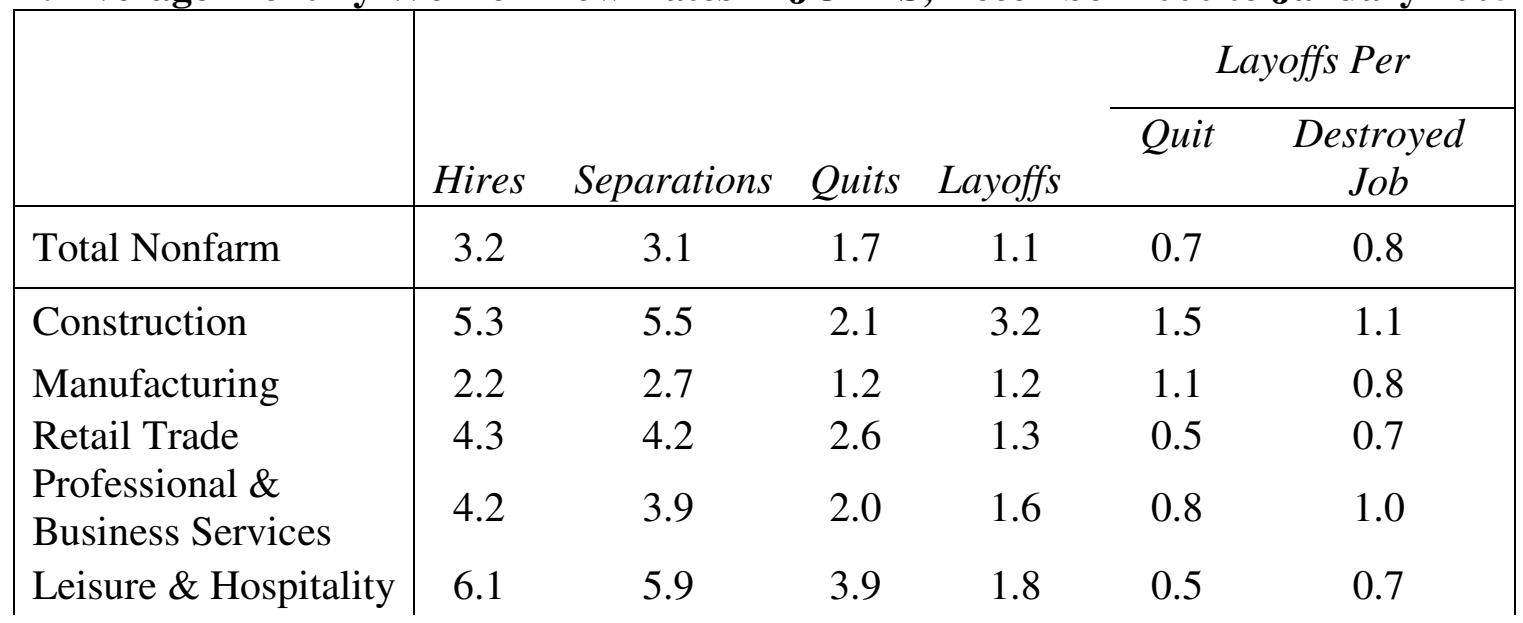

Notes: Estimates based on authors' tabulations of BED and JOLTS microdata. Rates are percentages of employment, calculated as described in the text. 